ББК 63.4

\author{
Организация конференциии и издание материалов проведень \\ при финансовой поддержке Российского фонда фундаментальных исследований, \\ проект № 19-09-20008
}

Утверждено к печати Ученым советом ИИМК РАН

Редакционная коллегия тома I: В. А. Алёкшин, Л. Б. Кирчо (отв. редакторы),

В. П. Никоноров, В. Я. Стёганцева; В. В. Терёхина

Рецензенты: д. и. н. Л. Б. Вишняцкий, д. и. н. А. А. Выборнов

Программный комитет конференции: академик РАН, д. и. н., проф. М. Б. Пиотровский

(Государственный Эрмитаж, почетный председатель); д. и. н. В. А. Лапшин (ИИМК РАН, председатель); д. и. н. А. В. Головнёв (МАЭ РАН, сопредседатель); д. и. н. В. А. Дергачёв (Высшая антропологическая школа, Молдова, сопредседатель); д. и. н. И. Ф. Попова (ИВР РАН, сопредседатель); академик АН Республики Узбекистан, д. и. н., проф. Э. В. Ртвеладзе (сопредседатель); к. и. н. А. В. Поляков (ИИМК РАН, зам. председателя); к. и. н. В. А. Алёкшин (ИИМК РАН, зам. председателя); д. и. н. Ю. Е. Берёзкин (МАЭ РАН); Dr., Prof. Н. Бороффка (Германский археологический институт, Германия); В. С. Бочкарёв (ИИМК РАН); Dr. Э. Кайзер (Свободный университет Берлина, Германия); к. и. н. М. Т. Кашуба (ИИМК РАН); д. и. н. Л. Б. Кирчо (ИИМК РАН); к. и. н. А. В. Кияшко (Южный федеральный университет); к. и. н. П. Ф. Кузнецов (СГСПУ);

к. и. н. Н. М. Малов (СНИГУ); к. и. н. В. П. Никоноров (ИИМК РАН); Ю. Ю. Пиотровский

(Государственный Эрмитаж); д. и. н., проф. Д. Г. Савинов (Институт истории СПбГУ);

к. и. н. В. Н. Седых (Институт истории СПбГУ); к. и. н. Н. Н. Скакун (ИИМК РАН);

к. и. н. Н. Ф. Соловьёва (ИИМК РАН); к. и. н. А. И. Торгоев (Государственный Эрмитаж); к. и. н. Е. А. Черлёнок (Институт истории СПбГУ)

Организационный комитет конференции: к. и. н. А. В. Поляков (ИИМК РАН, председатель);

к. и. н. В. А. Алёкшин (ИИМК РАН, зам. председателя); В. С. Бочкарёв (ИИМК РАН); ); к. и. н. М. Т. Кашуба (ИИМК РАН); д. и. н. Л. Б. Кирчо (ИИМК РАН);

А. И. Климушина (ИИМК РАН, отв. секретарь); к. и. н. В. П. Никоноров (ИИМК РАН); Ю. Ю. Пиотровский (Государственный Эрмитаж); В. Я. Стёганцева (ИИМК РАН); В. В. Терёхина

(ИИМК РАН, МАЭ РАН, отв. секретарь); к. и. н. Е. С. Ткач (ИИМК РАН); И. Ж. Тутаева (Государственный Эрмитаж); к. и. н. Е. А. Черлёнок (Институт истории СПбГУ)

Древности Восточной Европы, Центральной Азии и Южной Сибири в контексте связей и взаимодействий в евразийском культурном пространстве (новые данные и концепции): Материалы Международной конференции, 18-22 ноября 2019 г., Санкт-Петербург. Т. I. Древняя Центральная Азия в контексте евразийского культурного пространства (новые данные и концепции). К 90-летию со дня рождения патриарха евразийской археологии Вадима Михайловича Массона. - СПб.: ИИМК РАН, Невская Типография, 2019. — 291 с.

ISBN 978-5-907053-34-2

DOI 10.31600/978-5-907053-34-2 


\section{О РАННЕМ ЭТАПЕ РАСПРОСТРАНЕНИЯ БУДДИЗМА ЗА ПРЕДЕЛЫ ИНДИИ}

В. А. Гаибов ${ }^{\star}$, А. Б. Никитин ${ }^{* *}$

${ }^{\star}$ Институт археологии РАН, Москва, Россия; ${ }^{* *}$ Государственный Эрмитаж, Санкт-Петербург, Россия

DOI: $10.31600 / 978-5-907053-34-2-128-129$

Ключевые слова: буддиз, империя Маурьев, индо-греческие государства, Кушанское государство, Канишка, монеть.

Ранней истории буддизма, в том числе и вопросу о времени и путях его распространения за пределы Индии, посвящено много работ. Основными нашими источниками остаются сочинения буддийских авторов, созданные в Индии и на Цейлоне, китайские письменные источники, эпиграфика и, конечно же, археология. Античные же источники не выделяют буддистов среди других индийских религиозно-философских школ. Онесекрит (последняя четверть IV в. до н. э.) упоминает о гимнософистах, послы Селевкидов ко двору Маурьев (III в. до н. э.) знают брахманов и шраманов, но собственно Будду впервые упоминает только Климент Александрийский (II в. н. э.).

Царь Ашока из династии Маурьев, внук Чандрагупты, стал приверженцем буддизма и способствовал его распространению. До нас дошли несколько его надписей на пракритах, греческом и арамейском, установленных в пределах его владений (в Гандхаре и Арахосии), содержащие проповедь буддизма. Он обращался, в том числе, к правителям соседних эллинистических государств, вплоть до птолемеевского Египта, с предложением принять учение Будды. Но никаких явных результатов его проповеди за пределами Индии пока не обнаружено, а увлечение самого Ашоки буддизмом не встретило поддержки у элиты Империи Маурьев.

Отдельный вопрос - о влиянии буддизма на население индо-греческих государств, основанных на территории Северной Индии потомками греко-македонских завоевателей, пришедших на восток с Александром. Один из них, Менандр (II в. до н. э.) фигурирует под именем Милинды в палийском буддийском сочинении «Милиндапаньха». Нам хорошо известны чеканившиеся в Северной Индии монеты Менандра, но никакой явно буддийской символики на них не прослеживается, как и на монетах всех прочих индогреческих царей. Некоторые исследователи, впрочем, на основании этого палийского текста сделали преждевременный вывод об особом духовном единстве греческих философов и буддистов. Автор «Милиндапаньхи» просто использовал пропагандистский прием, приписав авторитетному правителю интерес к буддизму в целях пропаганды этого учения.

Непосредственно связана с буддизмом находка редкой золотой монеты в раннекушанском (середина І в. н.э.) могильнике Тилля-тепе в Северном Афганистане. На одной ее стороне изображен «лев, не знающий страха» - вполне буддийский символ, на другой - «поворачивающий колесо дхармы» персонаж, более всего напоминающий Геракла (обнаженное мускулистое тело, львиная шкура, головной убор со скальпом льва). Атрибуция этой фигуры вызвала споры среди исследователей. Мнения разошлись - либо это Будда, либо Геракл. Мы предлагаем очевидное решение - это Будда в ипостаси Геракла. Мощь Геракла необходима для вращения колеса дхармы, но вращать колесо - прерогатива Будды. В искусстве Гандхары Геракл со всеми его традиционными атрибутами (львиная шкура, палица) представлен на буддийских рельефах как ваджрапани, спутник и защитник Будды. 
Образование Кушанского государства устранило все препятствия к распространению буддизма на север. Кушанские правители, вероятно, были веротерпимы и не препятствовали этому, хотя говорить о какой-то целенаправленной поддержке ими буддизма пока не приходится. Кушанские монеты наглядно отражают религиозную политику властителей кушан. На монетах Вимы Кадфиза представлен исключительно Шива с быком Нандином. Это не значит, что Вима непременно был ярым шиваитом. Шиваизм был распространен в Северной Индии, где проживала основная масса населения кушанского государства. Царь должен был формально поддерживать религию большинства.

На монетах Канишки показаны самые разные божества, греческие, индийские, иранские. Есть и монеты с изображением Будды, но их очень мало. Тот же самый пантеон, за исключением Будды, присутствует и на монетах Хувишки. Васудева возвращается к шиваизму - на его монетах изображен Шива с быком. А Канишка III помещает на них исключительно восточноиранскую богиню Ардохш.

Разнообразие божеств на монетах Канишки и Хувишки может действительно отражать их особо толерантную религиозную политику, но может быть вызвано и экономическими причинами. Кушанские «медные драхмы», своего рода банкноты, не содержали драгоценного металла. Эти «медные банкноты» были обеспечены золотом, золотыми кушанскими монетами. В золоте у Кушан недостатка не было, оно регулярно поступало за счет торговли между Римской Империей и Индией. Однако изрядная часть этого золота оседала в храмах, в виде приношений божествам. Возможно, чтобы заставить храмы пустить эти сокровища в обращение (и дополнительно обеспечить номинальную стоимость «медных драхм»), кушанские правители и расширили ассортимент изображений божеств на монетах. Пуская золото в обращение, каждый храм заказывал на монетном дворе монеты с собственным божеством, таким образом, пропагандируя свой культ.

\title{
ON THE EARLY STAGE OF THE SPREAD OF BUDDHISM BEYOND INDIA
}

\author{
Vasif A. Gaibov ${ }^{\star}$, Aleksandr B. Nikitin ${ }^{\star *}$ \\ *Institute of Archaeology of the Russian Academy of Sciences, Moscow, Russia; ${ }^{*}$ The State \\ Hermitage Museum, St. Petersburg, Russia
}

Keywords: Buddhism, Maurya Empire, Indo-Greek realms, Kushan state, Kanishka, coins.

Greek and Roman authors do not distinguish Buddhists among the other religious communities of ancient India. There is no evidence of any spread of Buddhism beyond India before the 1stcentury AD. Greek rulers of Northwestern India were not affected by Buddhist propaganda despite the statement of "Milindapanha". The same concerns Kanishka, the king of the Kushans, presented in Buddhist texts as a benefactor of Buddhism.

One of the first images of Buddha appears on a rare gold coin from Tillya-tepe (Northern Afghanistan) of the 1st century AD, where Heracles-Buddha rotates the wheel of Dharma. There are very few coins of Kanishka with the images of Buddha, and they do not appear on coins of the other Kushan kings. Archeological finds (Buddhist monasteries, paintings, figurines) confirm the spread of Buddhism in Central Asia in the Kushan period and later, although it does not mean that Buddhism became at that time the official doctrine of the Kushan state. 